\title{
Treatment approach to apnestic breathing in Arnold Chiari malformation: any role of non-invasive ventilation?
}

\author{
Mediha TÜRKTAN ${ }^{\mathbf{1}}$ (ID) \\ Antonio ESQUINAS ${ }^{1}$ (ID)
}

${ }^{1}$ Department of Anesthesiology, Adana Cukurova University Faculty of Medicine, Adana, Turkey

${ }^{1}$ Adana Çukurova Üniversitesi Tıp Fakültesi, Anesteziyoloji Anabilim Dalı, Adana, Türkiye

2 Intensive Care Unit, Hospital Morales Meseguer, Murcia, Spain

${ }^{2}$ Morales Meseguer Hastanesi, Yoğun Bakım Ünitesi, Murcia, İspanya
Cite this article as: Türktan $M$, Esquinas $A$. Treatment approach to apnestic breathing in Arnold Chiari malformation: any role of non-invasive ventilation? Tuberk Toraks 2020;68(4):463-464.

\section{Yazışma Adresi (Address for Correspondence)}

Dr. Mediha TÜRKTAN

Adana Çukurova Üniversitesi Tıp Fakültesi, Anesteziyoloji Anabilim Dalı, ADANA - TÜRKIYE

e-mail: mediturktan@gmail.com

CCopyright 2020 by Tuberculosis and Thorax.

Available on-line at www.tuberktoraks.org.com

\section{Dear Editor,}

We read with interest the article entitled "Treatment approach to apnestic breathing in a patient with vocal cord paralysis due to Arnold Chiari malformation and tracheostomy" by Ayas $S$, et al. (1). Posterior fossa decompression is the first-line treatment of obstructive and/or central type apneas in patients with Arnold Chiari malformation. However, as the authors mentioned, it may not be success for every patients. In this context, CPAP and BIPAP modes are used as the first choice by the clinicians for non-invasive ventilation (NIV) therapy.

We consider that this original observation offers a key practical message; however, some key practical aspects need to take into account for a proper clinical application.

First, ventilator incompatibility and variability in patient needs are among the most important causes of NIV failure. In healthy adults, the minute volume decreases during sleep and this decrease may even more at different times of sleep. In the REM period, respiratory frequency increases, tidal volume and minute volume decreases. Central apnea and hyperpnea attacks are common, most of the upper respiratory tract muscles are atonic or hypoton- 
ic in this period. Motor neuron activity increases, there is a rapid and irregular respiration. If resistance increases in the upper airway or the airway is obstructed, patients enter a wakefulness period. For these reasons, new modes may be useful in NIV administration in obesity hypoventilation syndrome $(\mathrm{OHS}), \mathrm{COPD}$, neuromuscular diseases and chronic hypoventilation.

Second, in recent years, the most frequently used new ventilation modes are IVAPS (intelligent volume-assured pressure support), AVAPS (average volume assured pressure ventilation) and PAV. AVAPS is a combined mode that guarantees constant tidal volume in addition to pressure support. It was primarily applied to patients with OHS who did not respond to CPAP therapy. Thus, appropriate support is provided for the new respiratory condition during sleep and position changes. It has been shown that AVAPS mode applied in OHS and COPD patients provides a greater reduction in the level of $\mathrm{PaCO}_{2}$ in a shorter time than BIPAP and CPAP (2). Significant decrease in nocturnal $\mathrm{PaCO}_{2}$ was also observed with AVAPS compared to other modes $(2,3)$. The success rate in chronic obstructive pulmonary disease is reported as $76.4 \%$ (4). Intelligent volume-assured pressured support (IVAPS) was also associated with a reduction in the maximum $\mathrm{PaCO}_{2}$ during NREM sleep as compared to traditional BIPAP mode (5). Another reason for the NIV failure is the leak from the mask and it has been shown that mask leaks can be prevented with AVAPS mode (6). Ayas et al. successfully applied the AVAPS mode in patient with tracheostomy without leakage (1).

Finally, there are also studies showing that there is no difference between the new NIV modes and the traditional NIV modes in terms of sleep quality and patient compliance (7). New NIV strategies may be particularly useful in certain patients groups undergo- ing mechanical ventilation at home. However, the benefits of AVAPS and IVAPS have been demostrated in some small size studies and their roles on NIV threapy have not been fully defined by the literature. Thus, BPAP-CPAP is currently accepted standard NIV mode in central or obstructive type apnea.

More comprehensive studies are needed in this area for new NIV modes to be included in the central apnea management guideline.

\section{REFERENCES}

1. Ayas S, Şenel GB, Karadeniz D. Treatment approach to apnestic breathing in a patient with vocal cord paralysis due to Arnold Chiari malformation and tracheostomy. Tuberk Toraks 2020; 68(2): 175-83.

2. Storre $\mu H$, Seuthe B, Fiechter R, Milioglou S, Dreher $M$, Sorichter $S$, et al. Average volume-assured pressure support in obesity hypoventilation: A randomized crossover trial. Chest 2006; 130(3): 815-21.

3. Claudett KHB, Claudett MB, Wong MCS, Martinez AN, Espinoza RS, Montalvo M, et al. Noninvasive mechanical ventilation with average volume assured pressure support (AVAPS) in patients with chronic obstructive pulmonary disease and hypercapnic encephalopathy. BMC Pulm Med 2013; 13: 12.

4. Çiftci F, Çiledağ A, Erol S, Öz M, Acar D, Kaya A. Evaluation of the feasibility of average volume-assured pressure support ventilation in the treatment of acute hypercapnic respiratory failure associated with chronic obstructive pulmonary disease: A pilot study. I Crit Care 2017; 39: 232-7.

5. Khayat A, Medin D, Syed F, Moraes TJ, Bin-Hasan S, Narang I, et al. Intelligent volume-assured pressured support (IVAPS) for the treatment of congenital central hypoventilation syndrome. Sleep Breath 2017; 21(2): 5139.

6. Kaya PK, Kahveci FSS. Noninvaziv mekanik ventilasyon. [AVAPS: Average Volume-Assured Pressure Support]. 1. Baskı. Ankara, Akademisyen Yayınevi; 2018, 109-15.

7. Rabec C, Emeriaud G, Amadeo A, Fauroux B, Georges M. New modes in non-invasive ventilation. Paediatr Respir Rev 2016; 18: 73-84. 